\title{
BOODSKAP VAN HOOF VAN DIE VLOOT, VISE ADMIRAAL L.J. WOODBURNE, DVR, SD, SM.
}

Ek wil graag my beste wense aan u almal oordra by geleentheid van die 70 ste gedenkdag van die stigting van die SA Vloot.

Ons Vloot is vanjaar sewentig jaar oud. Alhoewel sewentig jaar nie 'n lang tyd is in vergelyking met die leeftyd van ander vlote nie, was dit tog lank genoeg vir ons eie tradisies en gewoontes om gevestig te raak en om ons 'n eie identiteit te gee waarop ons trots kan wees. Trots is natuurlik gegrond op prestasie, en ons vloot het, oor die jare, baie prestasies behaal - en opofferings gemaak, soos byvoorbeeld:

Ons baie opofferings gedurende die Tweede Wêreldoorlog, en die baie geleenthede waar dapperheid en professionalisme gelei het tot toekennings en eervolle vermelding;

ons suksesvolle aanskaffing van duikbote:
- sukses ter benutting van ons doelwitte in die era van maritieme missiele, ten spyte van die wapenverbod;

- tred hou met tegnologiese vordering in die wêreld:

- handhawing van ' $n$ hoë vlak van professionalisme ten spyte van rasionalisasie en ander probleme.

Ons sal voortgaan om ander regeringsdepartemente te steun in hulle diplomatieke inisiatiewe, of om ons maritieme bronne te beskerm: ons skepe was nog nooit voorheen so besig nie. Hulle het in die afgelope twee jaar 12 lande besoek en het ' $n$ reputasie verwerf as 'n klein, dog professionele, vloot.

Saam gaan ons die toekoms in met vertroue in die wete dat ons kan bou op die ondervinding van jare, om ' $n$ nasionale bate te wees vir ons land en al sy mense.

My beste wense aan u almal.

\section{MESSAGE BY CHIEF OF THE NAVY, VICE ADMIRAL L.J. WOODBURNE, DVR, SD, SM.}

I would like to extend my best wishes to you all on the occasion of the 70th anniversary of the founding of the SA Navy.

This year our Navy is seventy years old. Although seventy years is not considered a long time compared to some other navies, there has been ample time for our own traditions and customs to become established and to give an identity of which we can be proud. Pride, of course, comes from achievement, and our Navy has recorded many achievements - and sacrifices - over the years, for example:

Our many sacrifices made during WW II and the many occasions where gallantry and professionalism resulted in decorations, awards and commendations, Our successful acquisition of submarines, Successfully achieving our objectives in the maritime missile era in spite of the arms embargoes,
- Keeping pace with the world's technological advances,

- Maintaining a high level of professionalism in spite of rationalisation and many more.

Our tasks will continue to support other government departments with their diplomatic initiatives or the protection of our maritime resources. Neve: before have our ships been so busy. They have visited 12 countries in the last two years, and have earned a reputation as a small but professional navy.

Together we face the future with confidence secure in the knowledge that we can build on the experience that we have amassed over the years, to remain a national asset to our country and all its people.

My best wishes go out to you all. 


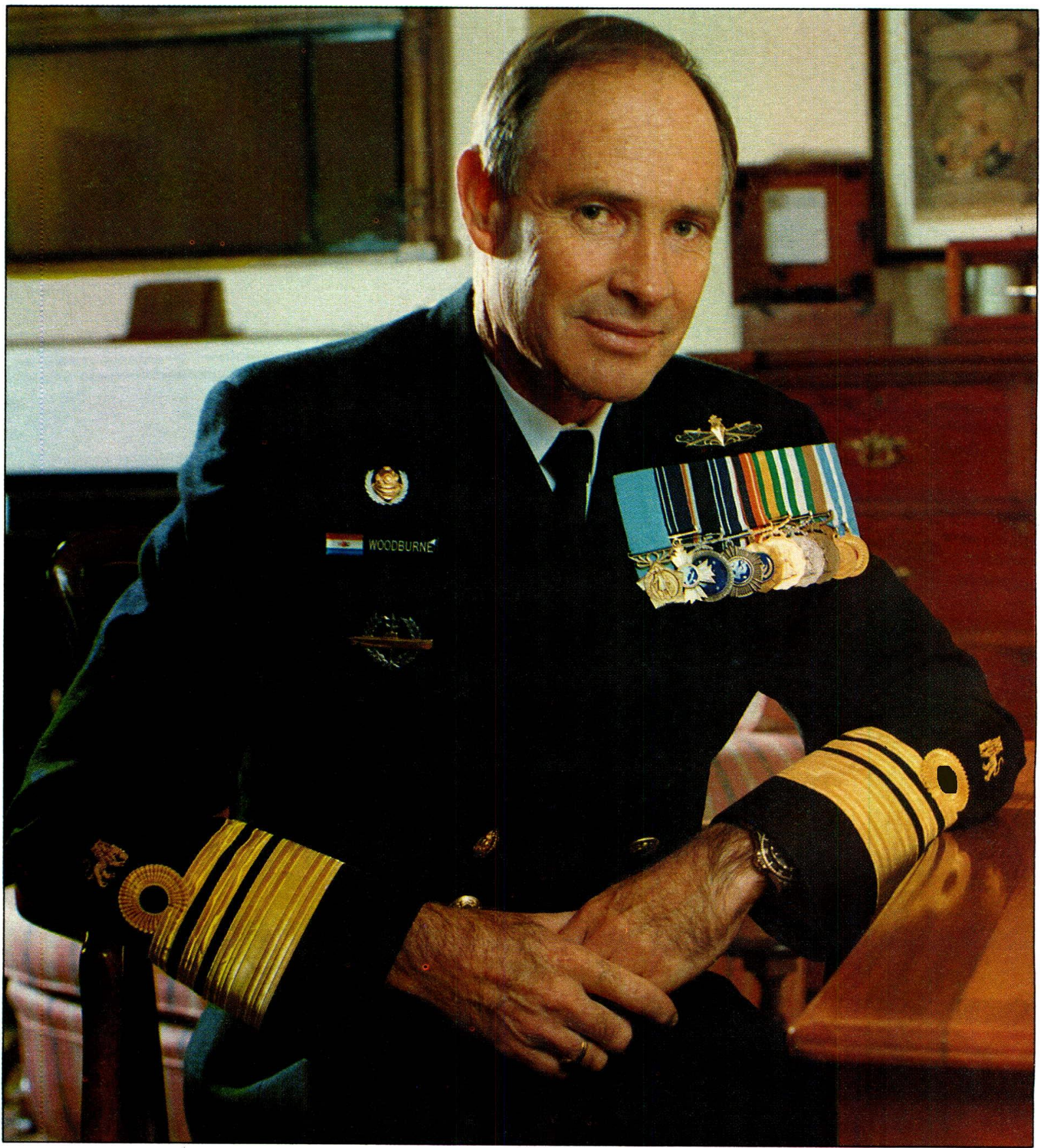

Vice Admiral L.J. Woodburne, DVR, SD, SM, Chief of the SA Navy. (Photo by Navy Photo Unit, Naval Printing Press, Simon's Town) 